\title{
CONTRIBUTION TO THE KNOWLEDGE OF THE ANTARGTIC ICE SHEET: A SYNTHESIS OF GLACIOLOGICAL MEASUREMENTS IN TERRE ADÉLIE*
}

\author{
By C. Lorius \\ (Laboratoire de Géologie, Collège de France, Paris)
}

\begin{abstract}
This paper is a synthesis of glaciological investigations conducted in Terre Adélie, mainly during the I.G.Y. The surface and bedrock profiles have been obtained along a $500 \mathrm{~km}$. line roughly perpendicular to the coast; the mean annual temperature has been studied as a function of altitude, and mean accumulation has been related to distance from the coast and surface slope. Stratigraphic studies made at Station Charcot again raise the problem of the determination of mean accumulation in certain parts of the Antarctic plateau; they provide a quadratic relationship between density and depth. The snow-drift studies lead to the following conclusions: wind velocity and density of drifting snow are functions of height above the surface, and the total transport depends on wind velocity. Lastly, measurements have been made of glacier flow near the coast. The paper ends with a schematic study of the mass balance in Terre Adélie; accumulation scems to be slightly larger than ablation, a result that is to be contrasted with the observed coastal retreat near Dumont d'Urville base.
\end{abstract}

Résumé. Cét article constitue une synthèse des mesures glaciologiques réalisées en Terre Adélie, notamment au cours de l'A.G.I. Les profils de la surface et du socle rocheux ont été obtenus le long d'un axe de $500 \mathrm{~km}$ approximativement perpendiculaire à la côte; le gradient des températures moyennes annuelles est étudié en fonction de l'altitude et l'on montre que l'accumulation moyenne est liée à la distance à la côte et à la pente. Les études stratigraphiques effectuées à la Station Charcot reposent le problème de la détermination de l'accumulation moyenne dans certains secteurs du plateau antarctique; elles permettent d'expliciter une relation du second degré entre la densité et la profondeur. L'étude de la chasse-neige permet de formuler les points suivants: la vitesse du vent et la densité de chasse-neige sont fonctions de la hauteur au dessus du sol; la quantité transportée dépend de la vitesse du vent. On rapelle enfin les mesures de vitesses de déplacement à la côte. On établit ensuite un schéma du bilan de masse en Terre Adélie; l'accumulation semble un peu supérieure à la somme des differentes formes d'ablation envisagées, contrairement à ce que l'on observe actuellement dans la région de la base Dumont d'Urville.

Zusammenfassung. Die vorliegende Arbeit stellt eine Zusammenfassung der in Adélie-Land ausgeführten glaziologischen Messungen, insbesondere während des I.G.J., dar. Die Profile der Oberfläche und des Felsuntergrundes erstrecken sich längs einer Achse von $500 \mathrm{~km}$ Länge ungefähr senkrecht zur Küste. Der Gradient der mittleren.Jahrestemperaturen wurde in seiner Abhängigkeit von der Höhe untersucht; es zeigt sich, dass der mittlere Auftrag von der Distanz zur Küste und vom Gefälle abhängt. Die stratigraphischen Untersuchungen in der Station Charcot tragen zu dem Problem der Bestimmung des mittleren Auftrages in gewissen Zonen des Antarktisches Inlandeises bei; sie erlauben, eine quadratische Beziehung zwischen Dichte und Tiefe zu formulieren. Aus der Untersuchung des Schneefegens können folgende Schlüsse gezogen werden: Windgeschwindigkeit und Dichte des Schneefegens sind abhängig von der Höhe über der Oberfläche; die transportierte Schneemenge hängt von der Windgeschwindigkeit ab. Schliesslich wird auf die Messungen von Fliessgeschwindigkeit des Eises an der Küste cingegangen. Mit dem Versuch, den Massenhaushalt von Adélie-Land zu erfassen, schliess die Abhandlung: Der auftrag scheint die Summe der verschiedenen in Betracht gezogenen Ablationsvorgänge leicht zu überwiegen; dieses Ergebnis steht im Gegensatz zu den derzeitigen Beobachtungen in der Station Dumont d'Urville.

\section{General Considerations}

During the I.G.Y. glaciological investigations were conducted in Terre Adélie (Antarctica) along a line through Dumont d'Urville base (lat. $66^{\circ} 40^{\prime} \mathrm{S}$., long. $140^{\circ} \mathrm{or} \mathrm{I}^{\prime} \mathrm{E}$.) and Station Charcot (lat. $69^{\circ} 22.5^{\prime}$ S., long. I $39^{\circ}$ or' E.) whence it extended to "Terme Sud" (lat. $7 \mathrm{I}^{\circ} \mathrm{O} 8^{\prime} \mathrm{S}$., long. $139^{\circ}$ I I ' E.), a distance of about $500 \mathrm{~km}$. approximately perpendicular to the coast (Fig. 1). This route includes the two main geographical divisions of the Antarctic Continent: (a) The plateau, remarkable for its high altitude, gentle slopes, very slight snow accumulation, homogeneous relief and low temperatures. These characteristics occur continuously beyond point B 35 (altitude $2,25^{6}$ m.a.s.l., distance to coast $25^{8} \mathrm{~km}$.). (b) The coastal area, extending from the sea to point $\mathrm{B}$ io (altitude $868 \mathrm{~m} . \mathrm{a} . \mathrm{s} . \mathrm{l}$., distance to coast $28 \mathrm{~km}$.), with steep slopes and more substantial accumulation. The prevailing higher temperature favours the appearance of melting features, the surface morphology is clearly differentiated

* This paper is a short summary of a book now in the press. 
by the action of stresses induced by the existence of rocky outcrops and above all by the presence of areas where the ice is flowing rapidly, producing crevasses.

\section{Ice Volume in Terre Adélie}

Ice thickness was determined at each surface point using altimetric, seismic and gravimetric profiles (Fig. 2). Altitudes were obtained for 124 stations by barometric surveying (Valtat and others, I960). Seismology (reflection shots) was used for the determination of

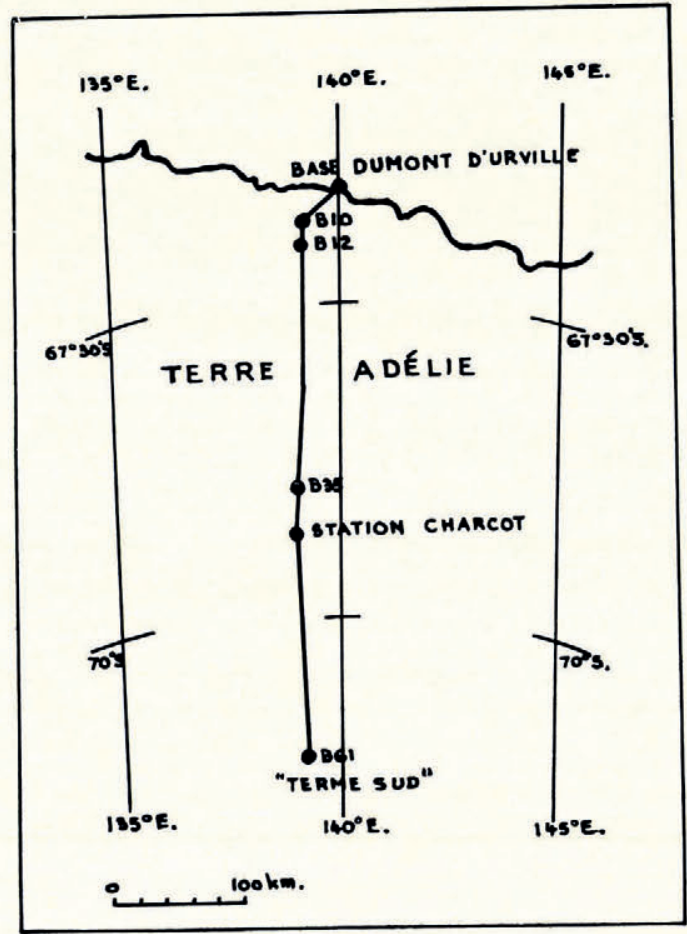

Fig. I. Terre Adélie. I.G.Y. Traverse route

bedrock depth at 27 of these points (Imbert, 1959). These data then allowed the rock surface profile to be plotted from the gravimetric results (Rouillon, i96o). For a mean bedrock depth of $-40 \mathrm{~m}$. (the actual depth varied from $-644 \mathrm{~m}$. to $+463 \mathrm{~m}$.), the surface profile is expressed by the equation

$$
\left(\frac{h}{2 \cdot 68}\right)^{2}+\left(\frac{55^{0}-D}{55^{0}}\right)^{2}=\mathrm{I}
$$

where $D$ is the distance to the coast in kilometres, and $h$ the height of the surface above the mean bedrock level in metres.

\section{Climatic Data: Mean Annual Temperatures}

Mean annual temperatures of the air at ground level were measured at fourteen points by lowering thermometers to the bottom of coring holes, the depth of which exceeded $10 \mathrm{~m}$.

Temperature variation plotted against altitude gives a straight line of slope $\mathrm{I} \cdot 1 \mathrm{O}^{\circ} \mathrm{C}$. for 
I $00 \mathrm{~m}$. altitude difference;* this is comparable with the figures published by Mellor ( 1960 ). A comparison of our measurements with those of Loewe ( I 956, p. I I4) along a line near long. $142^{\circ} \mathrm{E}$., with due allowance for the contour line pattern in Terre Adélie, leads to a correction of $\mathrm{I}^{\circ} \mathrm{C}$. for $\mathrm{I}^{\circ}$ of latitude. Figure 3 , which includes the results of two American parties to extend the line of our measurements, was plotted from temperature records reduced to lat. $66^{\circ} 5^{\circ} \mathrm{S}$. The slope of the resulting plot is $\mathrm{I} \cdot 04^{\circ} \mathrm{C}$. per $\mathrm{I} 00 \mathrm{~m}$.

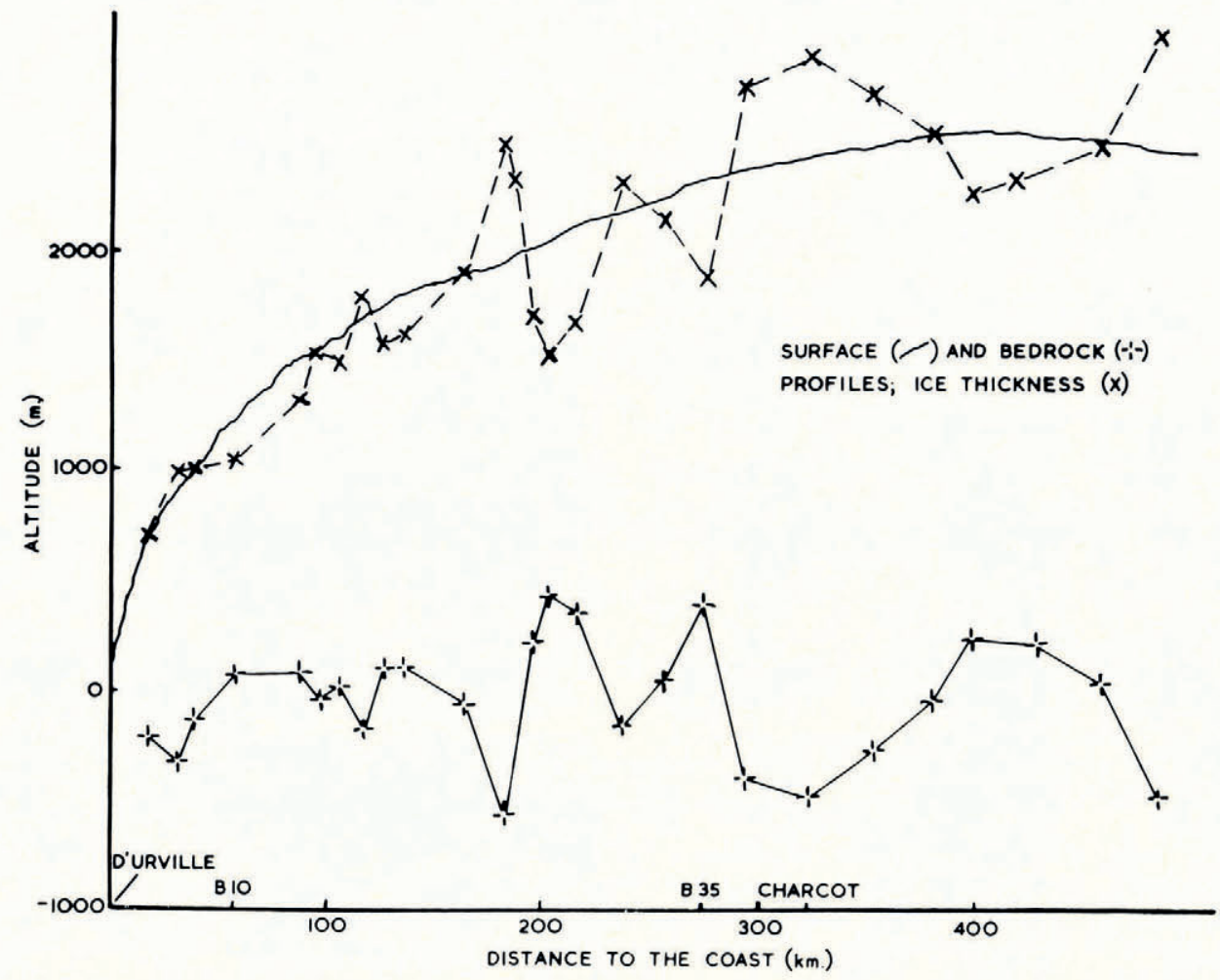

Fig. 2. Elevation and bedrock profiles; ice thickness in Terre Adélie

\section{Snow Accumulation}

A study of precipitation types at Station Charcot confirms the predominance of crystals such as prisms, needles and microcrystals usually produced at low temperatures and humidities. Replicas produced by the method developed by Schaefer (I94I) are excellent; photomicrographs of originals measuring less than $\mathrm{IO}^{-2} \mathrm{~mm}$. were obtained with a magnification of $\mathrm{I}, \mathrm{OOO}$.

The surface forms of the snow are basically of aeolian origin and sastrugi are oriented along $165^{\circ} \mathrm{E}$., thus making an angle of about $30^{\circ}$ to the west of the line of greatest slope (195 ${ }^{\circ} \mathrm{E}$.). This shift agrees with earlier observations (Dolgushin, I958, map; Hollin and Cameron, I 96 I, p. 838; Stuart and Heine, I96r, p. 100o) and with the theoretical predictions of Ball [1960]. Snow accumulation measurements (Cornet and others, I960) at 47 points over annual periods, using stakes regularly spaced along the track, reveal a very irregular distribution due to wind conditions; there is a marked maximum $(60.6 \mathrm{~cm}$. water equivalent) at B I 2 (altitude I, I04 m.,

* Air temperature recordings at Dumont d'Urville (altitude $40 \mathrm{~m}$.) and Charcot (altitude 2,400 m.) give a gradient of $\mathrm{I} \cdot 12^{\circ} \mathrm{C}$. per $100 \mathrm{~m}$. for 1957 and $\mathrm{I} \cdot 10^{\circ}$ C. per $100 \mathrm{~m}$. for $195^{8}$. 
distance to the coast $47 \mathrm{~km}$.), followed by a general decrease with distance from the coast. The last two remarks are comparable with, for example, the observations of Vyalov (1958, fig. 6, p. 27I). There may be various reasons for this decrease, such as the decrease in the number of atmospheric depressions towards the interior of the Continent, and the sudden rise in altitude in the coastal area, which favours condensation phenomena: the air which penetrates onto the plateau, having lost a certain amount of its vapour content, will generate less

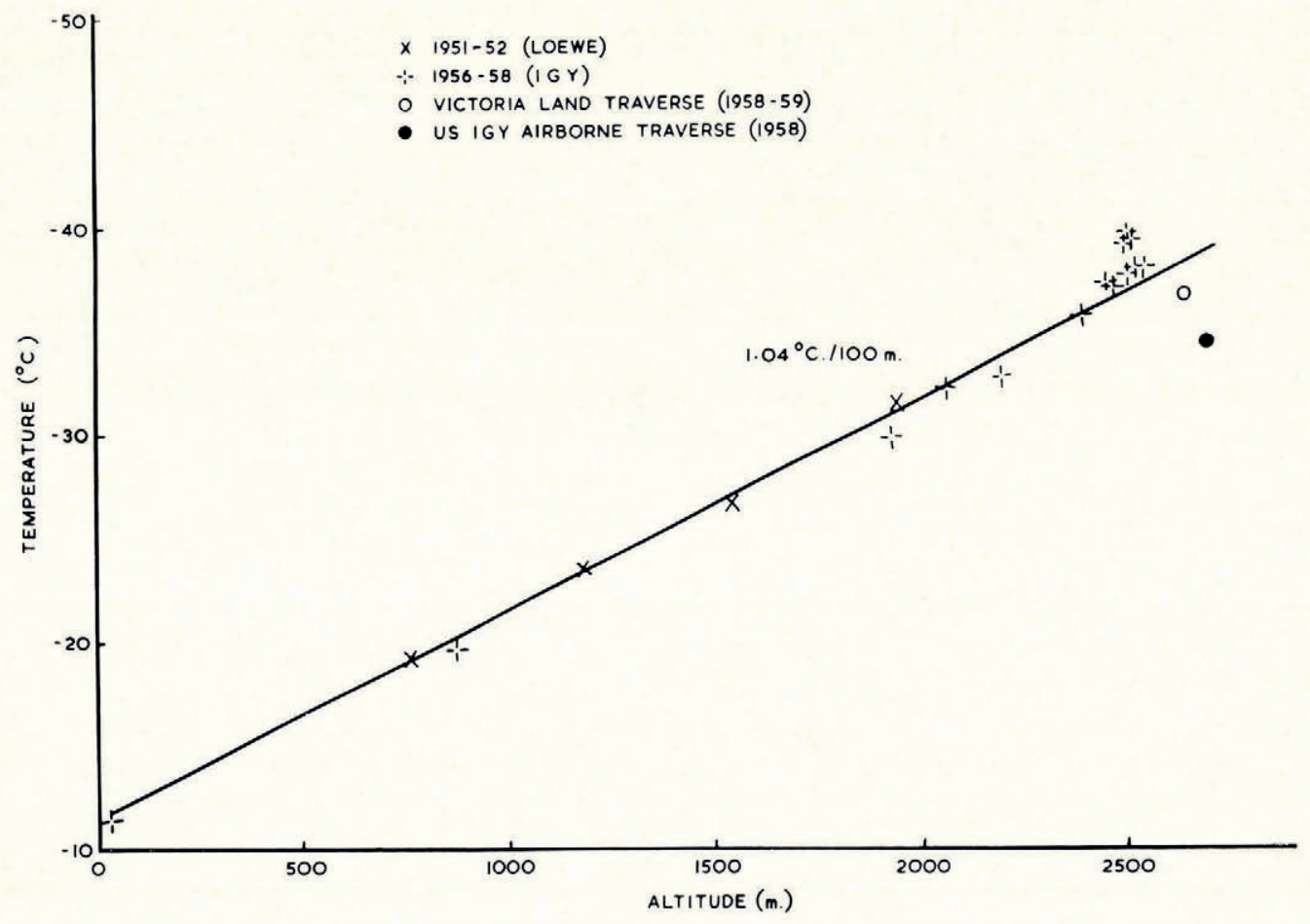

Fig. 3. Variation of temperature as a function of altitude

abundant precipitation. It seems that an altitude slightly above $\mathrm{r}, 000 \mathrm{~m} . \mathrm{a} . \mathrm{s} . \mathrm{l}$. is a clearly defined condensation level for the predominant air masses during depressions.

Measured accumulations have been grouped for sectors defined by comparatively large differences of mean slope to avoid the individual spread of readings due to local influence of the wind. This computation leads to the following rough equation

$$
A=\mathrm{Io}+\frac{\mathrm{IO00}}{D}+\mathrm{Iop}
$$

where $A$ is expressed in $\mathrm{cm}$. of water equivalent, $D$ is the distance to the coast in kilometres, and $p$ is the slope expressed as a percentage. Figure 4 shows the good agreement between measurements and the graphical representation of this formula except for the point in the border area, where the rapid drop in altitude is responsible.

\section{Building Up of the Firn Cover at Station Charcot: Annual Accumulation}

The determination of annual layers from stratigraphic studies has been dealt with by a number of authors (Benson, I96 I ; Schytt, I958; Shumskiy, r 955; Sorge, 1935, to mention but a 
few). In Terre Adélie the generally accepted methods were used to interpret our measurements of density, grain-size and hardness, for which continuous samples from various cores were available; these determinations were supplemented by ram hardness profiles (rammsonde). The summer layers are characterized by large-grained layers, low density and poor cohesion. The results are tabulated below, and are to be compared with the accumulation measured directly of $10 \cdot 2 \mathrm{~cm}$. water equivalent for 1957 and $18 \mathrm{~cm}$. for 1958 .

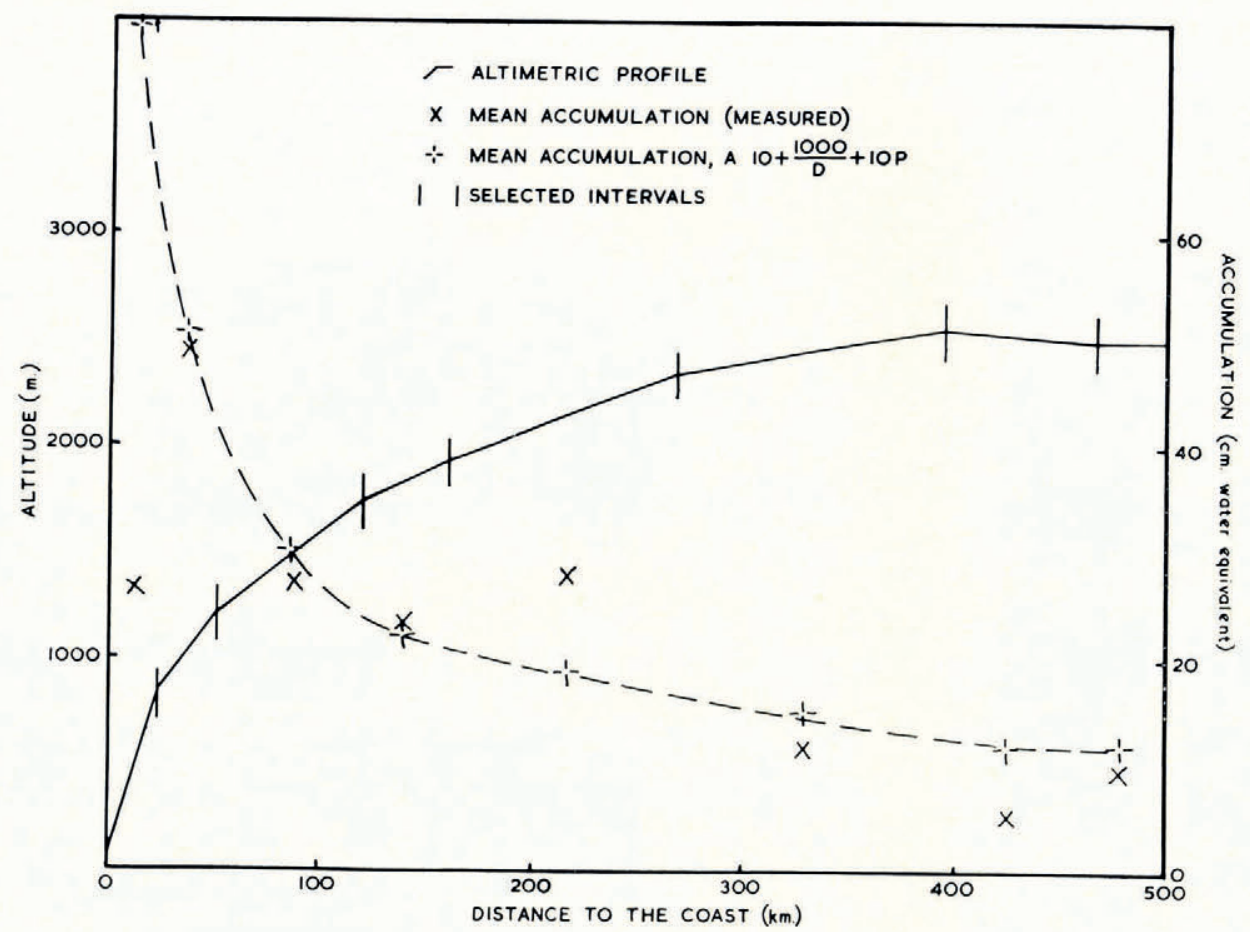

Fig. 4. Annual accumulation (water equivalent, 1957) versus distance to the coast

Table I. Accumulation at Station Charcot Determined from Core Stratigraphy

$\begin{array}{ccc} & \begin{array}{c}\text { Mean annual accumulation } \\ \mathrm{cm} \text {. water equivalent }\end{array} & \begin{array}{c}\text { Number of } \\ \text { years }\end{array} \\ \text { Core } 1 & 22 \cdot 6 & 37 \\ \text { Core } 2 & 13 \cdot 4 & 10 \\ \text { Core } 3 & 16 \cdot 6 & 17 \\ \text { Core } 4 & 18 \cdot 0 & 10 \\ \text { Core } 5 & 22 \cdot 4 & 23 \\ \text { Core 6 } & 28 \cdot 1 & 24\end{array}$

The spread of these figures raises the problem of the accurate determination of accumulation in areas where, as on the plateau of Terre Adélie, temperature is always well below $\mathrm{o}^{\circ} \mathrm{C}$. and accumulation is small and very irregular. Sastrugi, which are the main feature of the microrelief, may actually remain on the surface for a year or more, and besides this our observations did not enable us to identify a marked development of strongly settled winter layers which had been exposed to air temperature variations and solar radiation during the summer. Hence, in cases such as this, the counting of years will necessarily be inaccurate.

A seasonal study of firn layers was conducted on profiles of $20 \mathrm{~m}$. length using coloured 
nylon threads as reference marks, over a one-year period, during which the mean accumulation was $10.2 \mathrm{~cm}$. of water equivalent, seasonal deposits of comparable size show a marked difference as regards density: $0.375 \mathrm{~g} . / \mathrm{cm} .{ }^{3}$ in summer as against 0.426 in winter, the grainsize remaining however practically the same. This difference can be attributed to wind con-

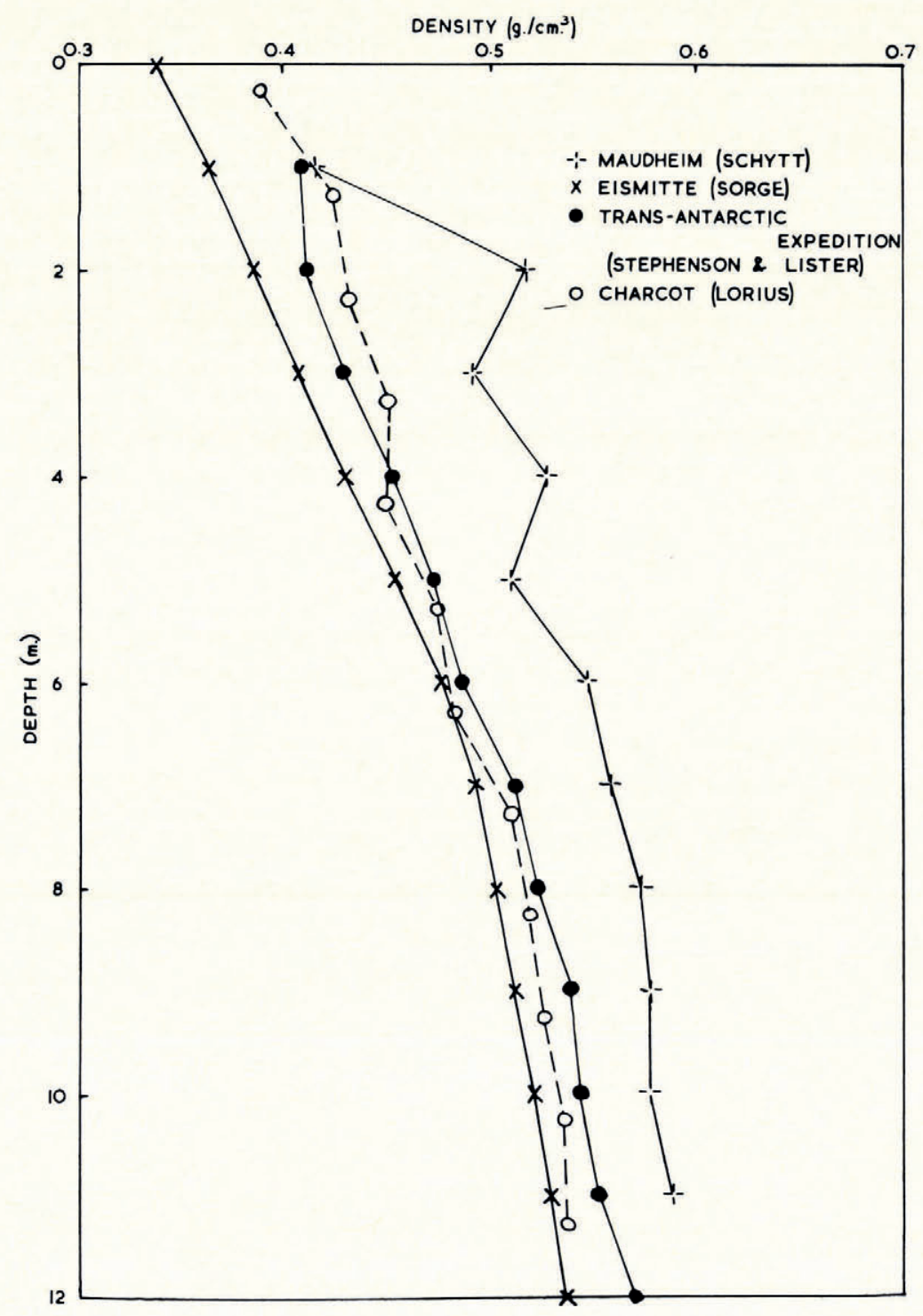

Fig. 5. Relationship between density and depth from various polar stations

ditions; the maximum and mean velocities are higher in winter $(10.5 \mathrm{~m} . / \mathrm{sec}$.) than in summer $(9.1 \mathrm{~m}$./sec.). This effect of wind velocity has been further assessed by a thorough investigation of the evolution of superficial deposits.

Porosity plays an important part in water-vapour transfer but, although we know that the density of winter deposits was 12 per cent above those of summer deposits, this is true only on 
A SYNTHESIS OF GLACIOLOGICAL MEASUREMENTS IN TERRE ADÉLIE

the average, and individual deposits may have atypical characteristics which could lead to an erroneous analysis of layers.

For all these reasons, stratigraphic interpretation of layers is not an accurate method of determining the mean accumulation in Terre Adélie. It therefore seems necessary to supplement the conventional methods of observation with some recently developed dating procedures (Botter and others, I96 I) based on deuterium and ${ }^{18} \mathrm{O}$ concentration. The simultaneous use of various techniques such as stratigraphy, dating, and measurement of electrical properties, is required to reach a high degree of accuracy.

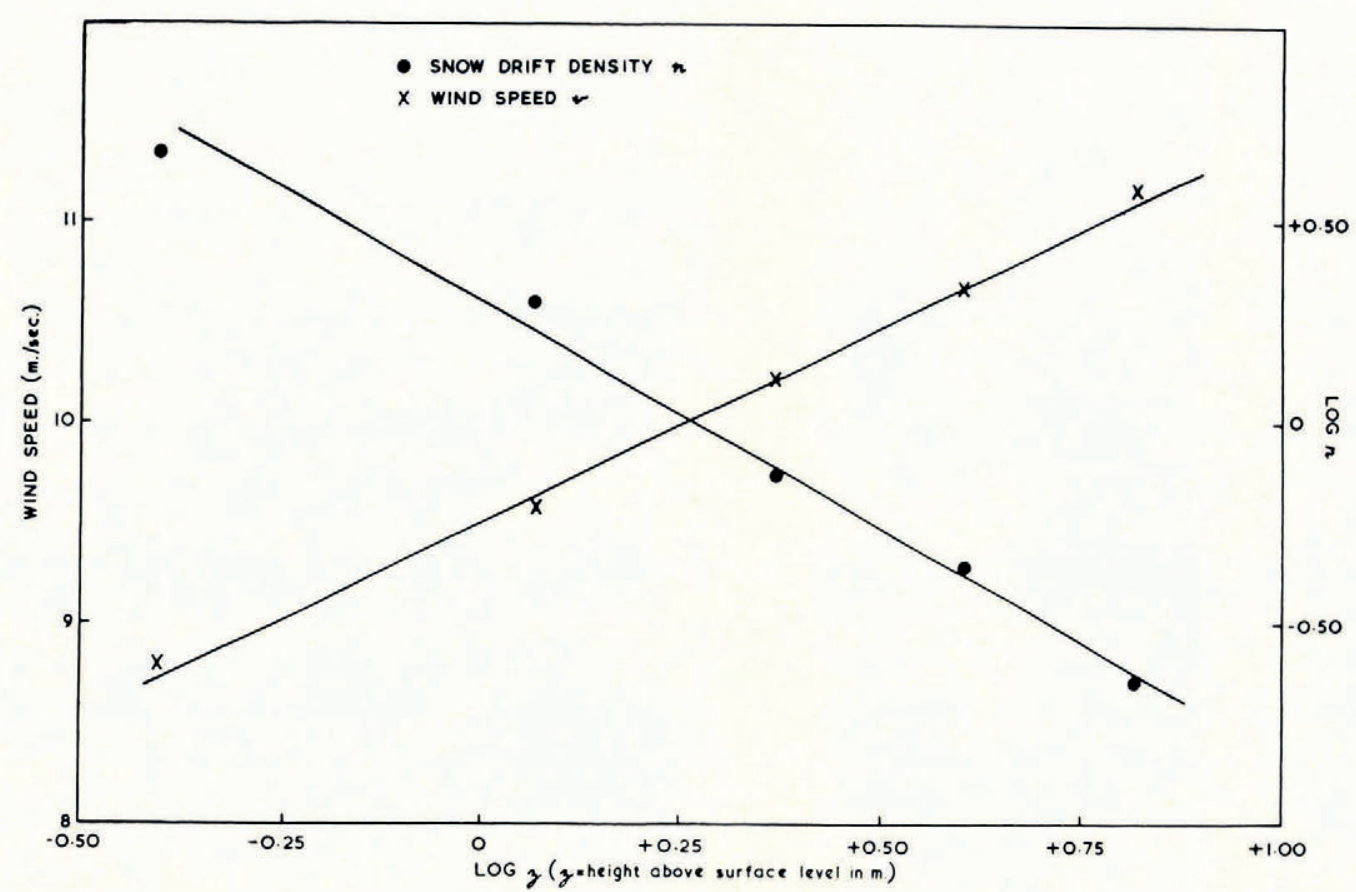

Fig. 6. Variation of windspeed and snow-drift density with the height above surface level, I f November 1957, I0.00-I2.30 hr.

The variation of density $d$ with depth $h$ is represented from o to $20 \mathrm{~m}$. by a formula derived from the mean of several corings by the method of least squares (previously used for this purpose by Bader).

$$
d=0.017 h-0 \cdot 0004 h^{2}+0 \cdot 4
$$

where $d$ is measured in grams per cubic centimetre and $h$ in metres. This curve, found for Station Charcot, is compared with the results of other authors in Figure 5.

\section{DRIFTING SNOW}

In I956, snow collected at Dumont d'Urville base* between o and $21 \mathrm{~m}$. altitude, corresponded to a transfer of about $400,000 \mathrm{~kg}$. per metre of coast per year for a mean wind velocity of $10.4 \mathrm{~m}$./sec., ignoring any efficiency factor which should be applied to allow for the use of improvised traps. In 1957 twenty-two series of measurements were made at five levels at Station Charcot, with simultaneous wind velocity recordings. A study of the results, based on

* Dumont d'Urville base is located on a rocky islet bordering the Continent. 
theoretical considerations of Loewe (1956, p. 125) and Dingle and Radok (196r) leads to the following conclusions: (a) wind velocity varies logarithmically with height above the ground, and (b) there is a linear relationship between the logarithms of density of drifting snow and altitude above the ground. A typical illustration of these relationships is given in Figure 6 . Furthermore, the transported amount of snow, determined by integration of the curve representing the weight of collected snow as a function of height (Fig. 7), is roughly proportional to the quantity of snow drifting across the $0.5 \mathrm{~m}$. level.

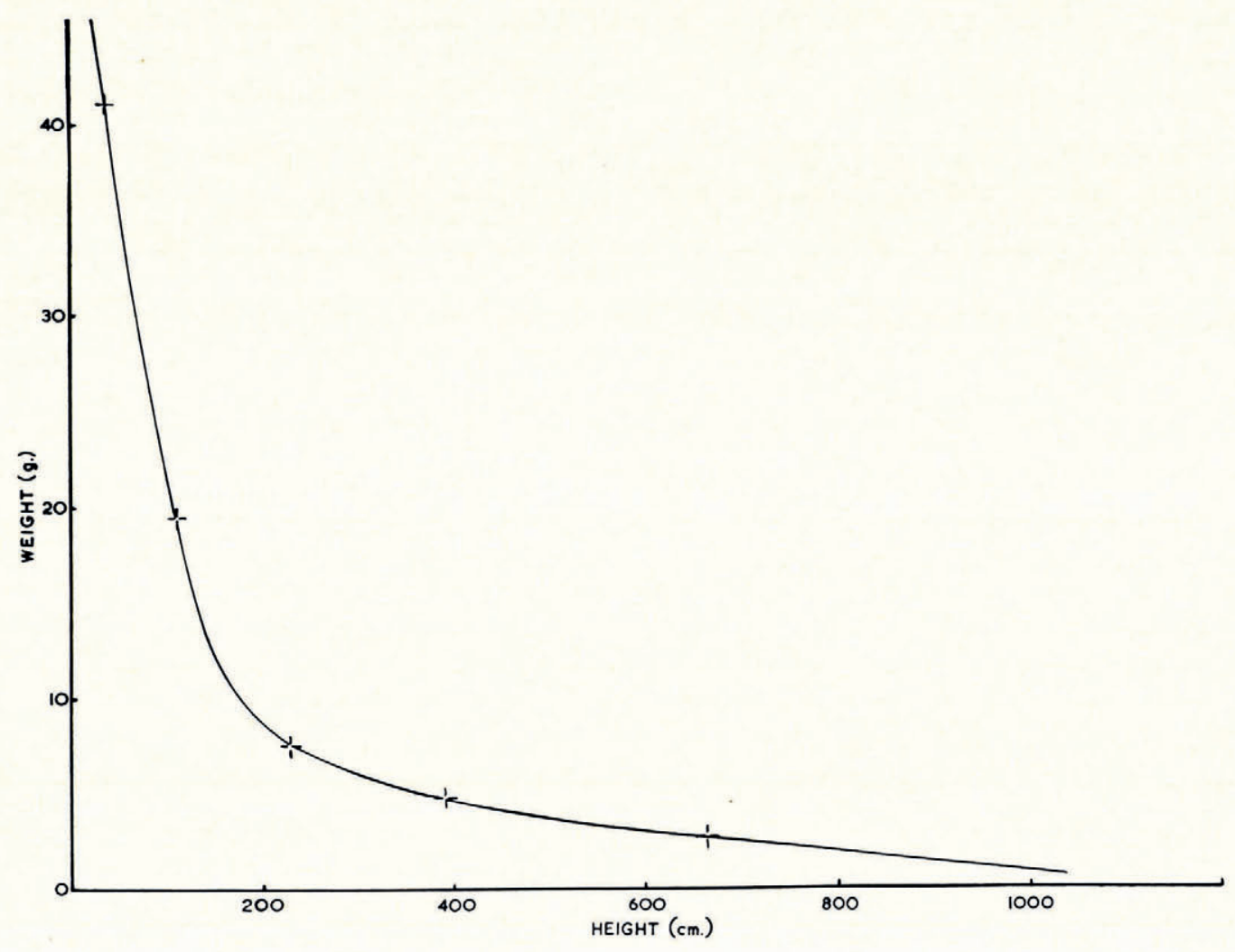

Fig. 7. Weight of snow drift versus height above surface level, 14 November 1957, 10.00-12.30 hr.

Use was made of 86 complete investigations carried out in 1958 on three levels at Station Charcot (Garcia, I960), and of the full set of micrometeorological observations concerned with drifting snow. For an average annual wind velocity of $9.2 \mathrm{~m}$. $/ \mathrm{sec}$., the annual transfer was about $290,000 \mathrm{~kg}$. for each vertical section of $\mathrm{I} \mathrm{m}$. width perpendicular to the wind. Again this figure ignores any efficiency factor. The quantity $Q$ of transported snow increases, as a first approximation, according to an exponential law as a function of wind velocity at $10 \mathrm{~m}$. Figure 8 , plotted from averages derived for velocity intervals of $\mathrm{I} \mathrm{m}$./ $/ \mathrm{sec}$., corresponds to the equation

$$
\Delta \log Q=\Delta v / 4 \cdot 6 \text {. }
$$

In this connection, the results of Dirigle and Radok ( $196 \mathrm{r}$ ) should be recalled; they found that

$$
\Delta \log Q=\Delta v / \mathrm{IO}^{\circ} 5 \quad \text { for } \mathrm{I} 5<v<29 \mathrm{~m} \text {. } / \mathrm{sec} \text {. }
$$


A SYNTHESIS OF GLACIOLOGICAL MEASUREMENTS IN TERRE ADÉliE

Results obtained by various authors are tabulated below.

Table II. Results Obtained by Various Authors for Quantity of Drifting Snow Authors

Loewe (1956, p. 131)

Stephenson and Lister (1959, p. 431)

Mellor and Radok [1960]

Dingle and Radok (196r, see fig. 4)

Wind velocity at $10 \mathrm{~m}$. $\mathrm{m} . / \mathrm{sec}$.

35

$10 \cdot 3$

28

$8 \cdot 9$

$16 \cdot 2$

28

36

Lorius (present work)*
Quantity of drifting snow $\mathrm{kg} . / \mathrm{m} . / \mathrm{hr}$. I 0,080

250

55,080

720

3,600

33,840

200,880

$3 \cdot 6$

$7 \cdot 2$

* The drifting snow measurements ignore an efficiency factor which could well double them.

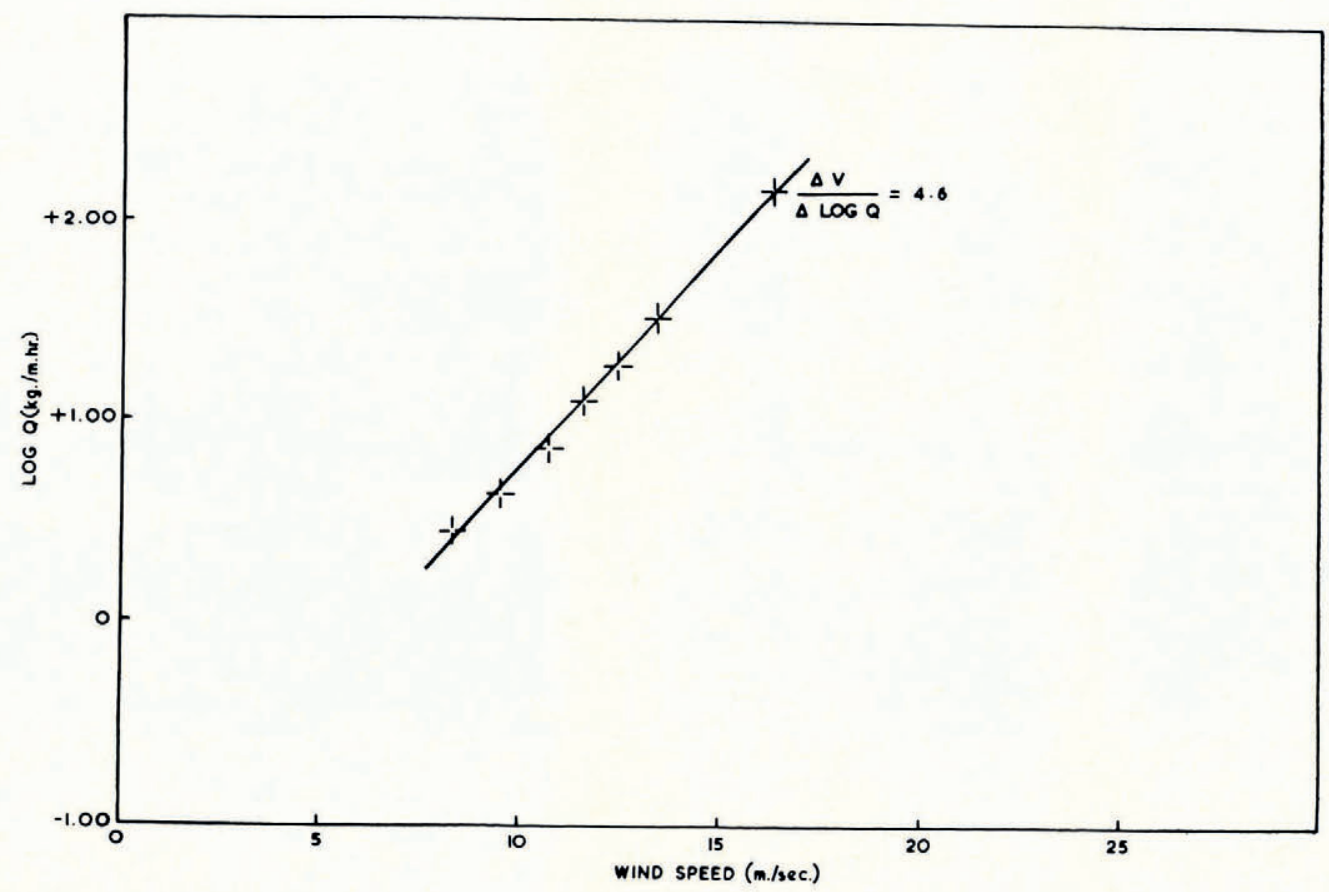

Fig. 8. Total weight of snow drift related to the windspeed

The fact that investigations were conducted at various points and dates, and hence did not have comparable surface conditions, accounts to some extent for the spread of the figures. The variety of recording instruments used is no doubt also largely responsible for the discrepancies. It is interesting to note the agreement between the present observations and the computations made by Vickers (1959) from theoretical considerations using wind profiles found by several authors. These are shown in Table III.

Table III. Quantity of Drifting Snow Calculated by Vickers using Various Wind Profiles Compared

Wind velocity at $10 \mathrm{~m}$. and author of profile $\mathrm{m} . / \mathrm{sec}$.

14.7 (Vickers)

$12 \cdot 4$ (Liljequist)

$14 \cdot 3$ (Bagnold) with Quantity Observed

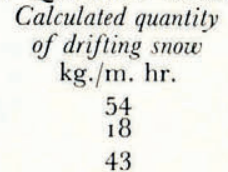

Measured quantity of drifting snow $\mathrm{kg} . / \mathrm{m}$. hr.

55

$19 \cdot 1$

$45 \cdot 7$ 
In this Table the wind velocities have been extrapolated from those at $\mathrm{I} \mathrm{m}$. using roughness factors given by Vickers.

\section{Glacier Flow}

As a result of measurements made on the Glacier de l'Astrolabe (Cornet, 1960), its mean annual velocity can be taken as $500 \mathrm{~m}$./yr.; its mean thickness is estimated at about $400 \mathrm{~m}$. In $195 \mathrm{I}$, Perroud (1955) recorded an average daily displacement of o. $55 \mathrm{~m}$. over a two month period using a reference mark located I $\mathrm{km}$. from the margin of the Glacier de la Zélée (approximate width I I km.); the velocity of the most conspicuous point of the cliff near this glacier was $9 \mathrm{~m}$. over a ten-month period, that is to say an annual velocity of $\mathrm{I} \mathrm{m}$. $/ \mathrm{yr}$. for an ice thickness of about $200 \mathrm{~m}$.

\section{Mass Balance in Terre Adélie}

All the above results can be used as a basis for a study of the mass balance in Terre Adélie. Wexler (196I) has shown the difficulty of such a study for the whole of Antarctica; seven different balances show a large spread (from -0.95 to $+\mathrm{I} \cdot 32 \times 10^{18} \mathrm{~g}$. $/ \mathrm{yr}$.).

Determination of accumulation. This balance has been taken for the sector whose edge is the coast of Terre Adélie, i.e. between long. $136^{\circ}$ E. and long. $142^{\circ}$ E. If we assume as a first approximation that the ice flows along the lines of greatest slope, we can determine graphically the accumulation area which corresponds to flow through the Terre Adélie coast (see Fig. 9). This area has then been divided into regions so that the data from Figure 4 can be used to calculate the net total accumulation. For 1957 this gave a net accumulation of $15.6 \mathrm{~km} .{ }^{3}$ water equivalent for a total surface area of $58,000 \mathrm{~km} .^{2}$.

Determination of ablation. Ablation can take place in the following ways:

surface melting

drifting snow

evaporation

oceanic melting

calving

subglacial melting.

We are not concerned here with surface melting, blowing snow and evaporation, because they have already been subtracted from precipitation before our determination of net accumulation. Let us examine the other factors.

Oceanic melting. This has not been studied experimentally in our case, and, having only a few measurements of sea temperature and salinity, this factor has been estimated from the calculations of Wexler ( 1960$)$. Using $\Delta T=\mathrm{I}^{\circ} \mathrm{C}$. for "the initial deviation of the water temperature above its freezing point as the water first comes in contact with the ice bottom", and an eddy conductivity of sea-water $A=\mathrm{I} 0 \mathrm{~g} . / \mathrm{cm}$. sec., and assuming the sea penetrates under the cliff for a distance of about $100 \mathrm{~m}$., we get a melting of the order of $0.8 \mathrm{~km} .3 / \mathrm{yr}$. (water equivalent).

Calving. The results on glacier flow lead us to the following conclusions:

\section{Formation}

Important glaciers

Secondary glaciers

Ice cliff

Rock outcrops

Total
Table IV. Loss of Ice by Calving in Terre Adélie

\begin{tabular}{cccc}
$\begin{array}{c}\text { Width } \\
\mathrm{km} .\end{array}$ & $\begin{array}{c}\text { Thickness } \\
\mathrm{km} .\end{array}$ & $\begin{array}{c}\text { Ice velocity } \\
\mathrm{km} . / \mathrm{yr} .\end{array}$ & $\begin{array}{l}\text { Calving } \\
\mathrm{km} .3 / \mathrm{yr} .\end{array}$ \\
34 & 0.4 & 0.5 & $6 \cdot 8$ \\
10 & 0.3 & 0.25 & 0.75 \\
265 & 0.2 & $0.01 \mathrm{I}$ & 0.6 \\
30 & - & - & 0 \\
\hline
\end{tabular}


Assuming an ice density of $0.9 \mathrm{~g} . / \mathrm{cm} .{ }^{3}$, there is thus a net loss of $7 \cdot 3 \mathrm{~km} .{ }^{3}$ of water equivalent. The mean of the results for the calving from the whole of Antarctica given by Wexler (1960), ignoring the three extreme values, and scaled down to the length of the coast-line of Terre Adélie gives the very similar value of $8 \mathrm{~km} .{ }^{3}$.

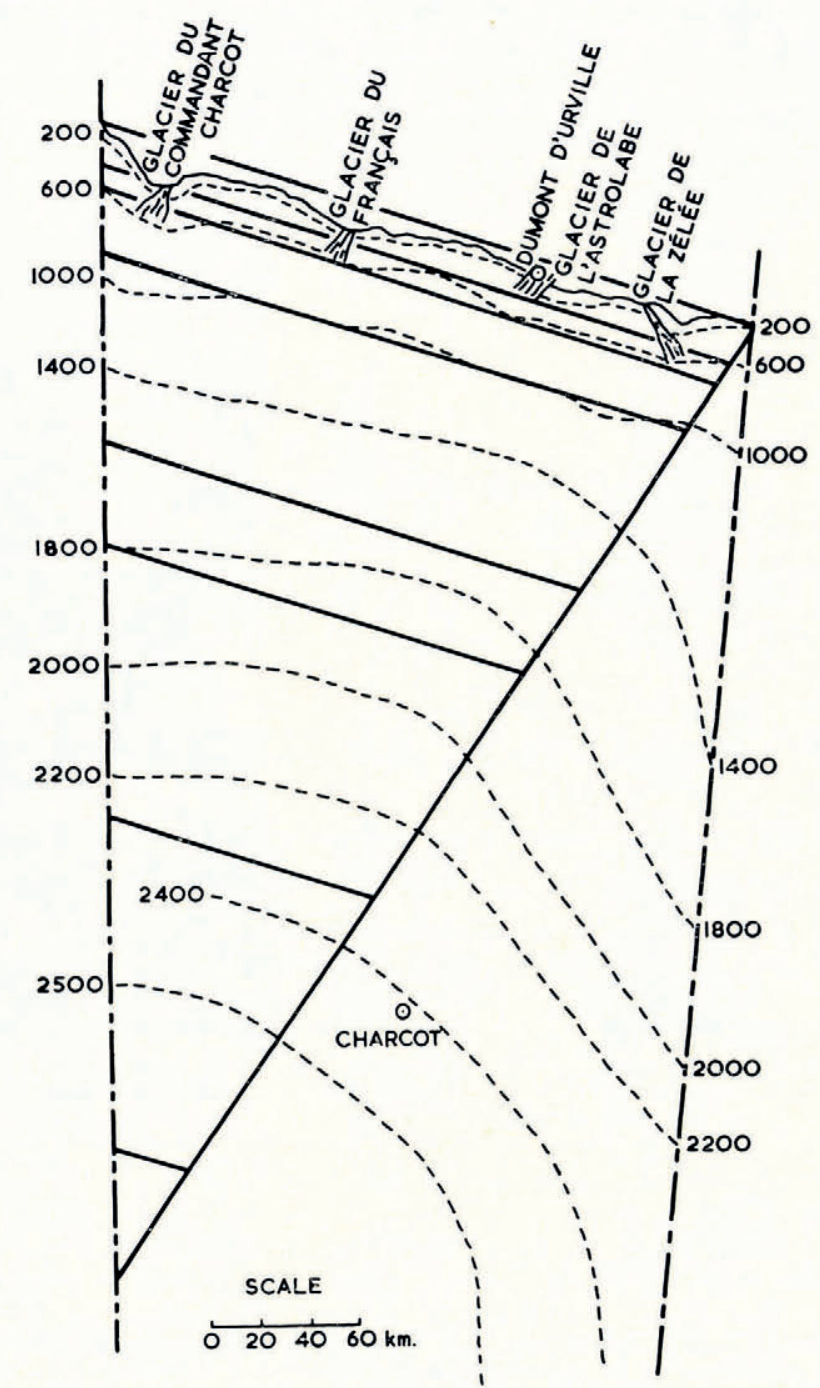

Fig. 9. Area of accumulation related to ablation through the coast of Terre Adelie

Subglacial melting. Two sources of heat must be taken into account. (a) Geothermal heat, for which we can use a value of $3^{8} \mathrm{cal} . / \mathrm{cm}^{2}{ }^{2} \mathrm{sec}$. (Jeffreys, 1952, p. 282). This provides $22 \times$ ${ }_{10} 0^{15} \mathrm{cal}$. $/ \mathrm{yr}$. for the whole area. (b) Transformation of potential energy in the ice, for which we can assume, as a first approximation, that the Antarctic Ice Sheet is in a steady state as regards its mass and shape; this means that each year energy is liberated equivalent to the work each snow accumulation does in descending to sea-level. Calculations for our eight regions (see Fig. 9) give a total value of $58 \times 10^{15} \mathrm{cal} . / \mathrm{yr}$. 
The maximum heat flux which could be conducted to the surface through the firn is calculated from the equation

$$
Q=\lambda \frac{T_{2}-T_{1}}{h}
$$

where $Q$ is the heat flux in cal. $/ \mathrm{cm}^{2}$ sec., $\lambda$ is the thermal conductivity $\left(5 \times 10^{-3} \mathrm{cal} . / \mathrm{cm}\right.$. sec. ${ }^{\circ} \mathrm{C}$.), $T_{2}$ is the mean temperature at the surface and $T_{1}$ the melting temperature of ice under the overlying pressure, both in ${ }^{\circ} \mathrm{C}$., and $h$ is the ice thickness in $\mathrm{cm}$. This calculation gives a value of $17.5 \times 10^{15} \mathrm{cal} . / \mathrm{yr}$.; only about one fifth of the total energy due to geothermal heat and potential energy transformation $\left(80 \times \mathrm{IO}^{15} \mathrm{cal} . / \mathrm{yr}.\right)$.

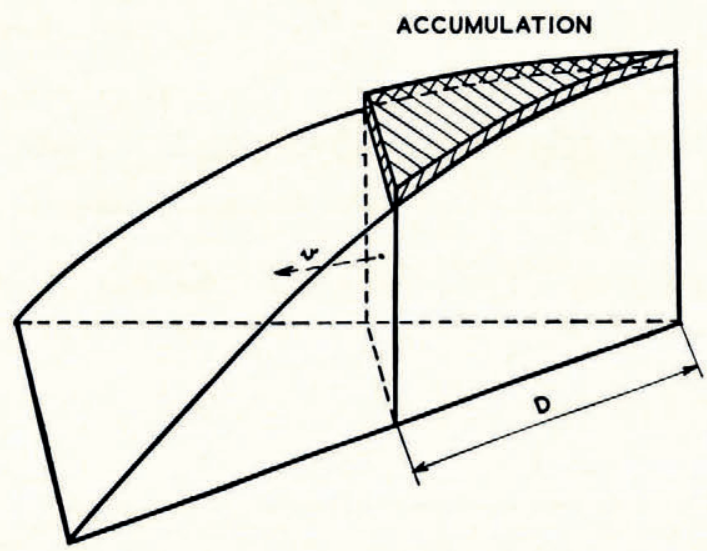

Fig. 10. Theoretical mean rate of outward movement

If we accept Nye's view (1951), all this energy is liberated in the ice at the ice-rock interface; so it scems that the bottom of the ice sheet should be at the melting point. The available energy would then melt $64 \times \mathrm{IO}^{15} / 8 \mathrm{o}$ or $0.8 \times \mathrm{IO}^{15} \mathrm{~g}$. of ice $\left(0.8 \mathrm{~km} .{ }^{3}\right.$ water equivalent). From Nye's hypothesis, Robin (1955, p. 525) calculates the work done in unit time at the icerock interface

$$
W=0 \cdot 88 v
$$

if $W$ is in kg.m. and $v$ is in m./sec. Determination of the rate of outward movement $v_{D}$ through a section $D$ is found as the integral of accumulation above that section divided by the area of section through which it flows, as shown diagrammatically in Figure ro.

Integration of the total energy from our eight sectors gives a value of $58 \times \mathrm{IO}^{15} \mathrm{cal} . / \mathrm{yr}$., and this together with $22 \times \mathrm{IO}^{15} \mathrm{cal} . / \mathrm{yr}$. of geothermal heat, makes a total of $80 \times \mathrm{IO}^{15}$ cal. $/ \mathrm{yr}$. which, taking conduction into account, would melt $0.8 \mathrm{~km} .{ }^{3}$ water equivalent. Thus these two different methods lead to the same result.

All these data for the mass balance in Terre Adélie are summarized in Table V.

Table V. Mass Balance for Area Discharging Icf. Through the Terre Adélie Coast

Area : 58,00o km. 2

Net accumulation

Ablation by calving

Ablation by oceanic melting

Ablation by subglacial melting

Mass balance
Ice volume: $100,000 \mathrm{~km} \cdot{ }^{3}$

$\mathrm{km} .{ }^{3}$ water equivalent

$$
\begin{array}{r}
15.6 \\
-7.3 \\
-0.9 \\
-0.8 \\
\hline+6.6
\end{array}
$$


Visual observations during the last three years nevertheless show a retreat of the ice wall in Terre Adélie with the appearance of rock. This retreat can perhaps be explained in one of the following ways; (a) due to movement at depth some ice included in the accumulation area is not calving through the coast of Terre Adélie; (b) current retreat results from past conditions, the time lag could be considerable as can be seen by comparing the mass balance, $6 \cdot 6 \mathrm{~km} .{ }^{3}$ with the ice volume, I00,000 km. ${ }^{3}$; (c) some ablation processes may have been underestimated; the calculations are of course only very rough because they have to be based on only a few scattered surface measurements made over a very short time interval compared with the times involved in so complicated a phenomenon.

MS. received 4. September 1961

\section{REFERENCES}

Ball, F. K. [1960.] Winds on the ice slopes of Antarctica. (In Antartic meteorology. Proceedings of the symposium held in Melbourne, February 1959. London, Pergamon Press, p. 9-16.)

Benson, C. S. 196r. Stratigraphic studies in the snow and firn of the Greenland Ice Sheet. U.S. Snow, Ice and Permafrost Research Establishment. Research Report 70.

Botter, R., and others. 1961. Sur la datation des couches de névé dans l'Antarctique à partir de leur concentration en deutérium, [par] R. Botter, C. Lorius, G. Nief. Comptes Rendus Hebdomadaires des Séances de l'Académie des Sciences, Tom. 252, No. 3, p. 437-39.

Cornet, A. 1960. Déplacement du glacier de l'Astrolabe et bilan de masse en Terre Adélie. Comptes Rendus Hebdomadaires des Séances de l'Académie des Sciences, Tom. 251, No. 3, p. 404-06.

Cornet, A., and others. I96o. Accumulation de neige en Terre Adélie, [par] A. Cornet, C. Lorius, G. Ricou. La Météorologie, Sér. 4, No. 57, p. 17 1-84.

Dingle, W. R. J., and Radok, U. 1961. Antarctic snow drift and mass transport. Union Géodésique et Géophysique Internationale. Association Internationale d'Hydrologie Scientifique. Assemblée générale de Helsinki, 25-7-6-8 1960. Colloque sur la glaciologie antarctique, p. 77-87.

Dolgushin, L. D. 1958. Les particularités morphologiques essentielles et les régularités des mouvements des glaciers de la marge de l'Antarctide orientale (d'après les observations (les relevés) dans la région des travaux de la partie continentale de l'Expédition Complexe Antarctique de l'Académie des Sciences de l'URSS). Union Géodésique et Géophysique Internationale. Association Internationale d'Hydrologie Scientifique. Symposium de Chamonix, ${ }_{1} 6-24$ sept. $195^{8}$, p. $111-24$.

Garcia, R. 1960. Mesures de transport de neige par le vent à la Station Charcot. La Météorologie, Sér. 4, No. 57, p. $205^{-13}$.

Hollin, J. T., and Cameron, R. L. I96ı. I.G.Y. glaciological work at Wilkes Station, Antarctica. Journal of Glaciology, Vol. 3, No. 29, p. 833-42.

Imbert, B. 1959. Détermination de l'épaisseur de glace en Terre Adélie. Comptes Rendus Hebdomadaires des Séances de l'Académie des Sciences, Tom. 248 , No. 4, p. 576-79.

Jeffreys, H. 1952. The Earth: its origin, history and physical constitution. Third edition. Cambridge, University Press.

Loewe, F. 1956. Études de glaciologie en Terre Adélie, I95I-1952. Paris, Hermann. (Actualités scientifiques et industrielles, 1247. Expéditions Polaires Françaises. Résultats scientifiques, No. 9.)

Mellor, M. I96o. Temperature gradients in the Antarctic Ice Sheet. Fournal of Glaciology, Vol. 3, No. 28 , p. $773-82$.

Mellor, M., and Radok, U. [1960.] Some properties of drifting snow. (In Antarctic meteorology. Proceedings of the symposium held in Melbourne, February, 1959. London, Pergamon Press, p. 333-46.)

Nye, J. F. 1951. The flow of glaciers and ice-sheets as a problem in plasticity. Proceedings of the Royal Society, Ser. A, Vol. 207, No. 1091, p. 554-72.

Perroud, P. I955. Astronomie-géodésie-cartographie, Terre Adélie 1951-1952. Paris, Expéditions Polaires Françaises. (Expéditions Polaires Françaises. Expéditions Antarctiques. Résultats Scientifiques, No. S.III.1.)

Robin, G. de Q. 1955. Ice movement and temperature distribution in glaciers and ice sheets. Fournal of Glaciology, Vol. 2, No. 18, p. $523-32$.

Rouillon, G. 1960. Anomalies de la pesanteur et profil de la calotte glaciaire antarctique en Terre Adélie. Comptes Rendus Hebdomadaires des Séances de l'Académie des Sciences, Tom. 251, No. 5, p. 762-64.

Schaefer, V. J. I94I. A method for making snowflake replicas. Science, Vol. 93, No. 2410, p. $239-40$.

Schytt, V. 1958. Glaciology. II. Snow studies at Maudheim. Norwegian-British-Swedish Antarctic Expedition, $1949-52$. Scientific Results (Oslo, Norsk Polarinstitutt), Vol. 4, A, p. I-64.

Shumskiy, P. A. 1955. Os rovy strukturnogo ledovedeniya. Petrografiva presnogo l'da kak metod glyatsiologicheskogo issledovaniya. Moscow, Izdatel'stvo Akademii Nauk SSSR. [French translation: Principes de glaciologie structurale. La pétrographie de la glace comme méthode d'étude glaciologique. Annales du Centre d'Études et de Documentation Paléontologiques, No. 22, 1957.]

Sorge, E. 1935. Glaziologische Untersuchungen in Eismitte. (In Brockamp, B., and others. Glaziologie. Leipzig, F.A. Brockhaus, p. 62-270. (Wissenschaftliche Ergebnisse der Deutschen Grönland-Expedition Alfred Wegener I929 und $1930 / 193$ I, Bd. 3.))

Stephenson, P. J., and Lister, H. 1959. Preliminary results of the glaciological work on the Trans-Antarctic Expedition, I $955^{-5}$. Fournal of Glaciology, Vol. 3 , No. 25, p. 426-31. 
Stuart, A. W., and Heine, A. J. 1961. Glaciological work of the 1959-6o U.S. Victoria Land traverse. Journal of Glaciology, Vol. 3, No. 30, p. 997-1002.

Valtat, B., and others. I960. Le nivellement barométrique Dumont d'Urville-Charcot-Terme Sud, [par] B. Valtat, S. Emery, A. Dourmap. La Météorologie, Sér 4, No. 57, p. 193-205.

Vickers, W. W. 1959. Wind transport of Antarctic snow. Transactions. American Geophysical Union, Vol. 40, No. 2, p. $162-67 ;$ I.G.Y. Bulletin (Washington, D.C.), No. 22 , p. 4-9.

Vyalov, S. S. 1958. Regularities of glacial shields movement and the theory of plastic viscous flow. Union Géodésique et Géophysique Internationale. Association Internationale d'Hydrologie Scientifique. Symposium de Chamonix, $16-24$ sept. I958, p. 266-75.

Wexler, H. 196o. Heating and melting of floating ice shelves. Journal of Glaciology, Vol. 3, No. 27, p. 626-45.

Wexler, H. 196r. Ice budgets for Antarctica and changes in sea-level. Journal of Glaciology, Vol. 3, No. 29, p. 867-72. 